\title{
THE NEW THIRD PARTY IN A TWO-PARTY SYSTEM? CIRCUMSTANCES AND IMPLICATIONS OF UKIP SUCCESS IN 2014 EUROPEAN PARLIAMENT ELECTIONS
}

\begin{abstract}
For a growing group of voters the UKIP party ceases to be a second choice, and it becomes a main party. But, contrary to popular belief, its electoral success is only partly due to its Eurosceptic program. Its growing support is rather the result of disappointment in policies of the main parties and a sense of alienation of a growing social group, failing to find its way in a liberal, multicultural society. Note, however, that the UK electoral system rewards parties that have geographically concentrated support, yet in case of UKIP it is distributed fairly evenly. For this reason, even a significant popular support will translate only in a small degree into the seats in the House of Commons. UKIP electoral successes has forced the major political parties to modify their policies, which manifested mainly in radicalization of their programs in the area of immigration and asylum policy, as well as their attitude towards the UK's membership in the European Union.
\end{abstract}

\section{Key words}

United Kingdom Independence Party, UKIP, British Politics, European Elections 2014

The result of United Kingdom Independence Party (UKIP) in the European Parliament elections in 2014 was a part of a "Eurosceptic earthquake" (Wintour, Watt, 2014), which struck a number of European Union countries. UKIP victory by obtaining $27.5 \%$ of the votes and winning one third of the UK's 73 seats,

\footnotetext{
* Błażej Choroś, Institute of Political Science, University of Opole, Poland, bchoros@ uni.opole.pl
} 